\title{
Krónikus gyermekbetegségek alakulása 1999-2017. években az Országos Statisztikai Adatfelvételi Program (OSAP 1021) jelentések alapján
}

\author{
Tendencies of chronic paediatric diseases in the period of 1999-2017. based on the \\ National Statistical Data Collection Programme (OSAP 1021) reports
}

\section{Összefoglalás}

Bevezetés: A háziorvosok, házi gyermekorvosok egységesen, az OSAP 1021-ben meghatározott szempontok szerint jelentik az általuk gondozott krónikus betegségeket két évtizede. Ez az időszak elég hosszú ahhoz, hogy a rendelkezésre álló adatsorokból elemzéseket végezzünk.

Adatok, módszer: Azadatoka KSH honlapjáról lekérdezhetők39 betegség tekintetében.Jelen közleményben az 1999-2017. közötti évek adatsorai kerültek felhasználásra. A betegségek vagy betegségcsoportok 10000 före (veleszületett rendellenességek esetén 1000 före) vetítve kerültek elemzésre.

Eredmények: A háziorvosok, házi gyermekorvosok által kezelt krónikus betegségek száma a vizsgált 19 évben a 0-18 éves korosztályban megkétszereződött. 2017-re kiemelkedően megnőtt az allergiás, továbbá idegrendszeri és mentális betegségek száma 1999-hez viszonyítva. Változatlanul magas a veleszületett rendellenességek és visszamaradt magzati növekedés és alultápláltság, a rövid terhességi időtartammal és alacsony születési súllyal kapcsolatos károsodások száma.

Megbeszélés: A betegségek gyakoriságának növekedése jelentős teherrel jár az egyes betegekre, családokra, de az egészségügyi ellátórendszerre is. Érdemes a betegségek okait kutatni, a hangsúlyt a primer prevencióra helyezni. A jelentés adattartalmát és módját 20 év után célszerü lenne felülvizsgálni, korszerüsíteni.

Kulcsszavak: háziorvos, házi gyermekorvos, jelentés, krónikus gyermekbetegségek, trend

\begin{abstract}
Introduction: GPS, paediatricians have been reporting the chronic illnesses they have been caring for uniformly for two decades, according to the criteria defined in OSAP 1021. This period is long enough to perform analyses from the available data sets.

Data, method: The data can be queried from the CSO website for 39 diseases. In this article the data series for the years between 1999-2017 were used. Diseases or groups of diseases were evaluated per 10,000 people (1,000 people for congenital disorders).

Results: The number of chronic diseases treated by general practitioners and paediatricians doubled in the 0-18 year age group. By 2017, the number of allergic, neurological and mental illnesses has increased significantly compared to 1999. The frequency of congenital anomalies, foetal growth retardation and
\end{abstract}


malnutrition, as well as impairments due to shortened gestational period and low birth weight, remained high.

Discussion: The increase in disease frequency places a significant burden on individual patients, families, but also on the health care system. It is worth researching the causes of diseases, with an emphasis on primary prevention. The data content and method of the report should be reviewed and updated after 20 years.

\section{EGÉSZSÉGTUDOMÁNY}

2021;65(1): 50-65

HEALTH SCIENCE

Közlésre érkezett: 2020. december 7 . Submitted: 7 December 2020

Elfogadva: 2021. janur 26.

Accepted: 26 January 2021

Levelezési cím/Correspondence:

$$
\text { Dr. Bényi Mária }
$$

Állami Egészségügyi Ellátó Központ 1089 Budapest, Delej u. 51.

E-mail: benyi.maria@gmail.com Tel.: +36 $1476-1154$

\section{Bevezetés}

A gyermekek egészségi állapotának monitorozása több szakterületen is folyik hazánkban. A védőnői és iskola-egészségügyi ellátásról szóló jelentések hosszú évek óta nyomon követik a gyermekek bizonyos betegségeit a magzati kortól egészen a felnőtt korig'. Az egészség egyik speciális, korai elváltozásokat monitorozó rendszere a veleszületett rendellenességek nyilvántartása több mint 5 évtizede múködik hazánkban².

Az „Iskoláskorú gyermekek egészségmagatartása” (Health Behaviour of School Children (HBSC)) elnevezésű, az Egészségügyi Világszervezettel együttműködésben megvalósuló nemzetközi kutatások - melyek önbevalláson alapulnak - elsődlegesen az életmódbeli szokásokat kutatják, de a vizsgálatok rámutatnak egyes fiatalkori betegségekre is ${ }^{3}$.
1999. évtől létezik az Országos Statisztikai Adatfelvételi Programon (OSAP) belül egy adatgyüjtés, amelyből a háziorvosi, házi gyermekorvosi gondozásban megjelenő krónikus betegségekről kaphatunk képet ${ }^{4}$. Az adatszolgáltatás, kevés változtatással, hosszú ideje múködik, és lehetőséget teremt arra, hogy a háziorvosi, házi gyermekorvosi gondozásban megjelenő krónikus betegségek trendjét megvizsgáljuk. Fontos megjegyezni, hogy a jelentésben nem a betegek száma jelenik meg, mivel egy gyermek több jelentendő betegségben is szenvedhet.

Ezzel az összesítéssel az a célunk, hogy egy átfogó képet adjunk a két évtizede múködő háziorvosi, házi gyermekorvosi jelentések eredményeiről. Az egyes betegségek számának növekedése vagy csökkenése mögött álló feltételezett okokat csak érintjük. Az adatsorok bemutatásával a jelentő háziorvosoknak szeretnénk visszajelzést adni, tükröt tartani; a szúkebb gyermekgyógyászati szakterületek ismerőinek értékelési alapot nyújtani további elemzésekhez, a megelőzésben dolgozó kollégáknak pedig ráirányítani a figyelmét azokra a pontokra, ahol égető szükség lenne a prevencióra.

\section{Adatok, módszer}

Az általunk használt háziorvosi, házi gyermekorvosi adatoknak az OSAP 1021 jelú táblázat képezi alapját. Az adatokat a KSH honlapján található adatbázisból nyertük, a „Tájékoztatási adatbázis Felnőttek betegségei” menüpont alatt, az 1999-2017. közötti időszakra vonatkozóan ${ }^{5}$. Az elérhető adatok az adott évben nyilvántartott, meghatározott krónikus betegségekben szenvedők prevalencia adatait tartalmazzák. Az adatszolgáltatás a 0-18 éves korú gyermekekre vonatkozik. A betegségek nemenként és korcsoportonként (0-11 hó, 1-4 év, 5-14 év, 15-18 év) vizsgálhatóak. Jelenleg 39 különböző betegség szerepel a listán. (Ezek tételesen 
az eredmények fejezetben az 1. ábrán láthatók, a psoriasis kivételével.) 2009. évtől a gümőkór, a vírusos májgyulladás és a rachitis aktív esetei kikerültek a jelentési rendszerből, viszont bekerült a psoriasis.

A jelentés kétévente készül, így az elmúlt 19 évre vonatkozóan betegségenként 10 adat áll rendelkezésre. A vizsgált időszak alatt végbement növekedés mértékét a 2017/1999. évi adatok hányadosával fejeztük ki minden vizsgált betegségre. Bemutatásra kerülnek a nyers adatok is, ezek jelzik a betegségek egészségügyi ellátásra nehezedő terhét. A változás trendje nyomon követhető a 10000 före vetített adatokkal. A veleszüle- tett rendellenességekkel kapcsolatban kiemelten vizsgáltuk a 0-11 hónapos korosztályra vonatkozó adatok időbeni alakulását, ezt 1000 före vetítve mutatjuk be.

\section{Eredmények}

A háziorvosok, házi gyermekorvosok által kezelt gondozást igénylő betegek száma a vizsgált időszakban - miközben a 0-18 éves korúak száma 441 ezer fövel csökkent-megduplázódott (1. ábra).

(Y06) Elhanyagolás vagy elhagyás (E01.0) Jódhiányos golyva

Q00-Q07) Idegrendsz. veleszül. rendell. (E43-E44) Fehérje- és energiahiányos alult. (K25-K28) Gyomor-, nyombél-, gastrojejun. fekély (H49-H52) A szem betegségei (M91) A csípõ és medence osteochondrosisa (I10-I15) Magas vérnyomás (E84) Fibrosis cystica (L40) Psoriasis* (G80) Csecsemõkori agyi bénulás Technikai összesen (átlag) (N00-N08,N10-N16) Glomerularis betegségek (M08) Fiatalkori ízületi gyulladás (Q60-Q64) A húgyrendsz. veleszül. rendell.

(F19) Pszichoaktív szer okozta ment. zav. (P05,P07) Visszamaradt magzati növ. és alult. (E00-E90) Endokrin , tápl. és anyagcsere bet. (F89) A psychés fejlődés rendellenességei (Q65) A csípổ veleszületett deformitásai

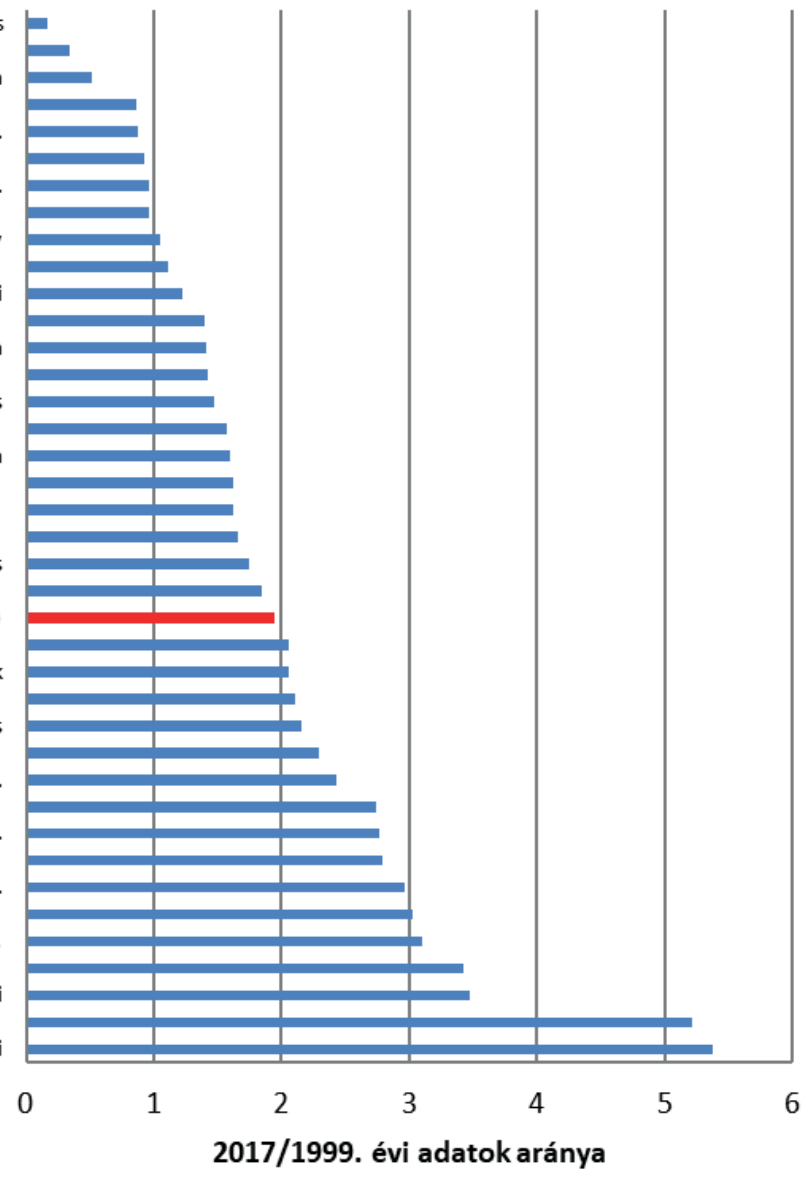

1. ábra: A gondozásra szoruló krónikus betegségben szenvedők számának alakulása 0-18 éves korban 1999-röl 2017 évre az OSAP 1021 alapján Magyarországon 
Országos adatok alapján a 38 féle betegséggel kezeltek közül 8 betegségben szenvedők tekintetében lett kevesebb a nyilvántartottak száma a jelentések szerint a vizsgált időszak alatt. Három betegség esetében jelentős mértékű a prevalencia csökkenése, az 1999. évi adatokhoz képest az elhanyagolás, elhagyás 17\%-ra, a vakság és csökkentlátás 35\%-ra, a jódhiányhoz társuló diffúz golyva 52\%-ra esett vissza.

A mentális retardációk aránya 86\%-ra, az idegrendszer veleszületett rendellenességei 87\%-ra, az ajak és szájpad hasadékok 93\%-ra, a fehérje és energiahiányos állapotok 96\%-ra, a kalóriatöbblet miatti elhízás is 96\%ra csökkent.

Az összes többi (30 féle), már 18 éve jelentett betegség száma emelkedett a kezdő évhez képest, ahogy a 2009. év óta vizsgált psoriasis is. Legnagyobb mértékben a csípő veleszületett rendellenessége, illetve a coeliakia prevalenciája növekedett - több, mint 5-szörösére. Több, mint háromszorosára nőtt a pszichés fejlődési rendellenességek, az atopiás dermatitis, az endokrin, táplálkozási és anyagcsere betegségek miatt nyilvántartott betegek száma.

A veleszületett rendellenességeket és bizonyos születés körüli eseményeket külön vizsgáltunk a 0-11 hónapos korcsoportra vonatkozóan 1999-2017. között (1. táblázat). Az öt betegség csoportból 3 jelentősebb növekedést mutat. (Az 1000 azonos korúra vetített adatok az 5. ábrán láthatók.)

A növekedés mértékét egyes betegségcsoportok tekintetében ábrákon is bemutatjuk, 10000 főre vetített adatok felhasználásával. Az összevonással ugyan a betegségcsoporton belül a betegségek közötti esetleges eltérő irányú vagy mértékű változások elmosódnak, de egy kompaktabb képet nyújtanak a nagyszámú betegről. Egy ábrán a megközelítően azonos arányban előforduló betegségeket jelenítjük meg, melyek dinamikája azonban eltérő.

A 2. ábrán látható, hogy az allergiás betegségek kimagaslóan megugrottak, de az endokrin táplálkozási betegségek növekménye is figyelemre méltó.

A szülés körüli anomáliák és veleszületett rendellenességek nagyságrendi szempontból és az emelkedés tekintetében is szinte azonos pályát írnak le a mentális viselkedési zavarokkal a vizsgált időszakban. A mozgásszervi betegségek aránya kisebb mértékben növekedett, és a legutóbbi, általunk vizsgált évben már csökkent a 10000 före vetített arány. Egyes látószervi betegségekkel nyilvántartottak száma nőtt, másoké csökkent, - mint, ahogy a 9. táblázatban részletesen látható -, de összességében enyhe emelkedést mutatnak.

A 10000 före számított legkisebb arányszámú betegségcsoporton belül a felszívódási zavarok miatt kezeltek arányának emelkedése kiugró (4. ábra). A magas vérnyomással gondozott betegek aránya, úgy tünik, nem emelkedik tovább, és ez látható a daganatos betegségek esetén is.

A születés körüli eseményeket és a veleszületett rendellenességek alakulását 0-11 hónapos korcsoportra külön is bemutatjuk 1000 före (5. ábra).

A csípő veleszületett rendellenességeinek száma és aránya nagymértékben nőtt, az utolsó vizsgált évig. Az utóbbi 2 évig nőtt a húgyrendszeri betegséggel kezeltek száma és aránya is. A visszamaradt magzati növekedés - a következményeivel együtt - mértékletesen, de folyamatosan növekszik.

1. táblázat A veleszületett rendellenességek alakulása az OSAP 1021 alapján 0-11 hónapos korban $1999-$ röl 2017. évre Magyarországon

\begin{tabular}{|c|c|c|c|c|c|}
\hline \multirow[b]{2}{*}{ Időszak } & \multicolumn{5}{|c|}{ Betegség száma (0-11 hó) } \\
\hline & $\begin{array}{l}\text { Csípő veleszü- } \\
\text { letett rendelle- } \\
\text { nességei Q65 }\end{array}$ & $\begin{array}{l}\text { Húgyrend- } \\
\text { szer rendel- } \\
\text { lenességei } \\
\text { Q60-Q64 }\end{array}$ & $\begin{array}{c}\text { Idegrendszer } \\
\text { rendellenessé- } \\
\text { gei } \\
\text { Q0O-Q07 }\end{array}$ & $\begin{array}{l}\text { Nyúlajak, } \\
\text { farkas- } \\
\text { torok } \\
\text { Q35-Q37 }\end{array}$ & $\begin{array}{c}\text { Vissza- } \\
\text { maradt } \\
\text { magzati } \\
\text { növekedés } \\
\text { P05, P07 }\end{array}$ \\
\hline $\begin{array}{l}\text { 2017./1999. évi ada- } \\
\text { tok aránya }\end{array}$ & 6,41 & 2,2 & 1,16 & 1,01 & 1,91 \\
\hline
\end{tabular}




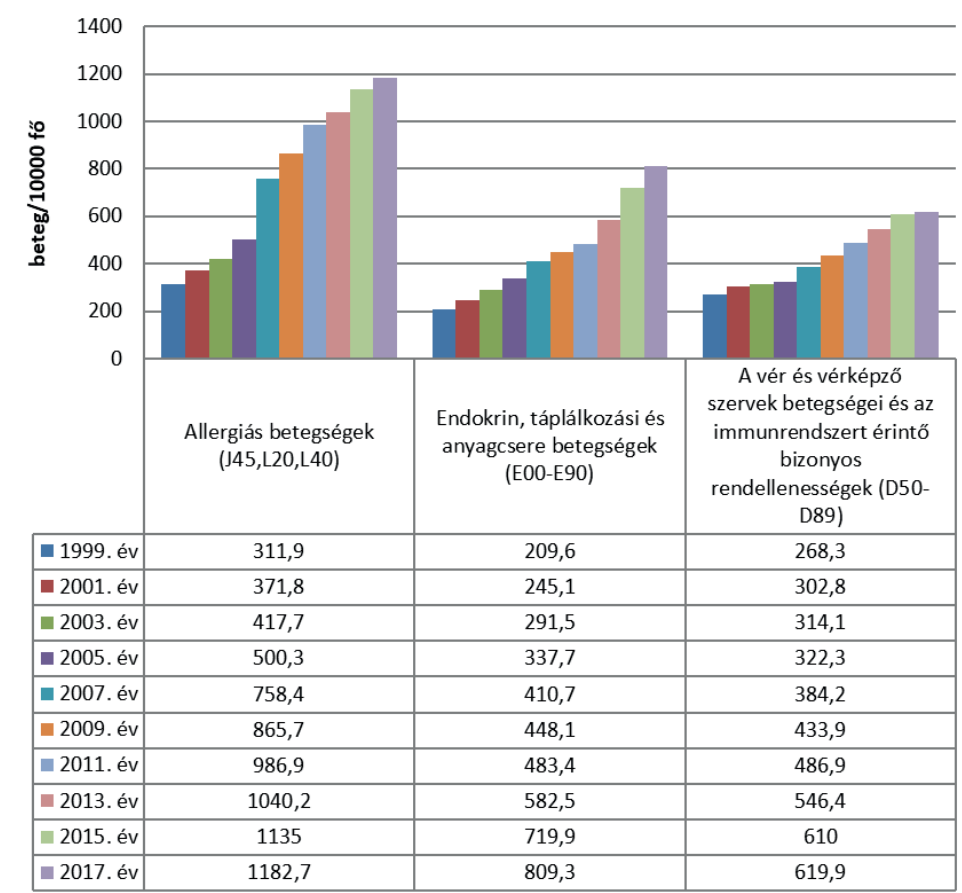

2. ábra: Allergiás-, endokrin- és anyagcsere betegségek, vér- és vérképzó szervek betegségeinek alakulása a 0-18 éves korcsoportban 10000 före az OSAP 1021 alapján 1999-2017. években Magyarországon

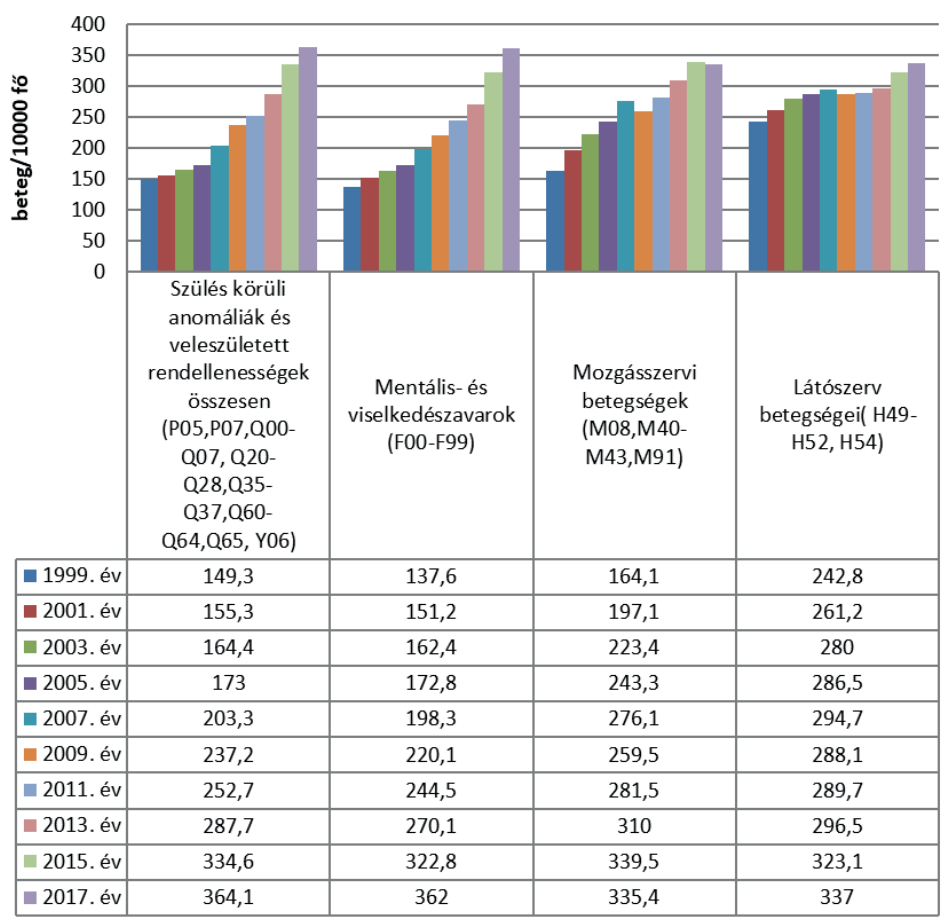

3. ábra: Szülés körüli anomáliák, veleszületett rendellenességek, mentális viselkedészavarok, mozgásszervi betegségek, a szem betegségei a 0-18 éves korcsoportban 10000 före az OSAP 1021 alapján 1999-2017. években Magyarországon 


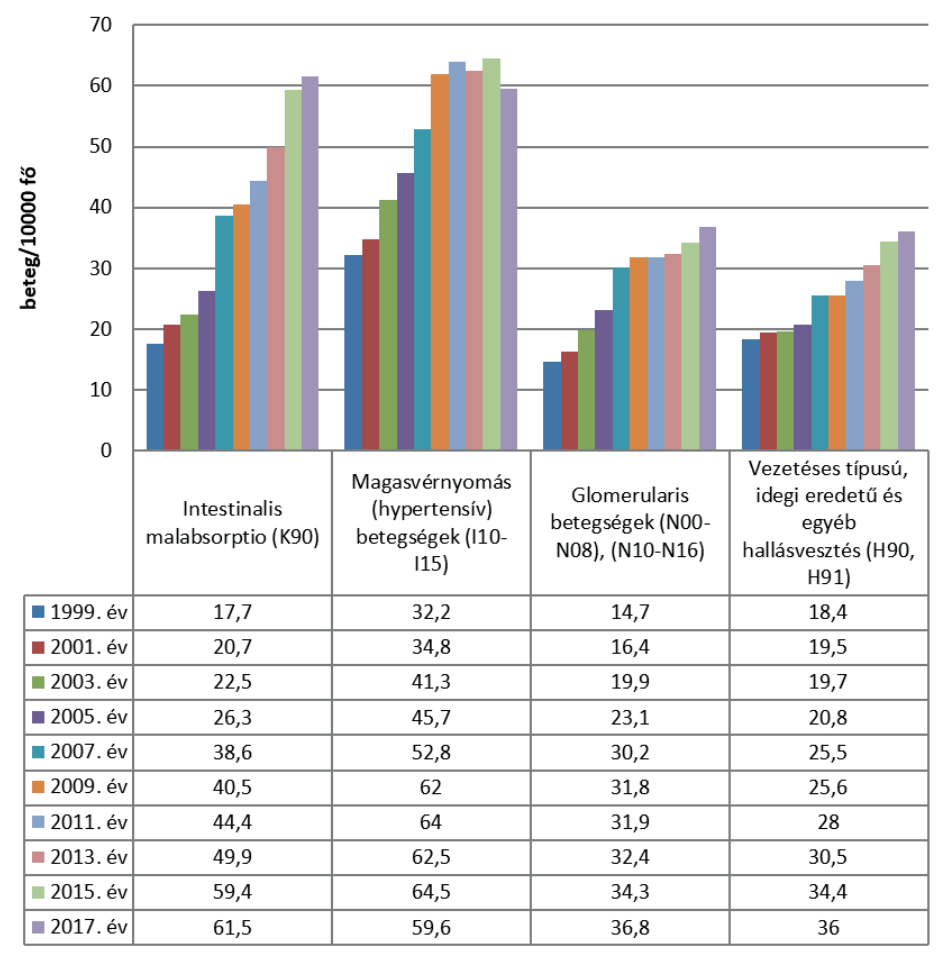

4. ábra: Intestinális malabsorptio, magasvérnyomás, glomeruláris betegségek és vezetéses típusú, idegi eredetú és egyéb hallásvesztéssel kezelt betegek számának alakulása a 0-18 éves korcsoportban 10000 före az OSAP 1021 alapján 1999-2017. években Magyarországon

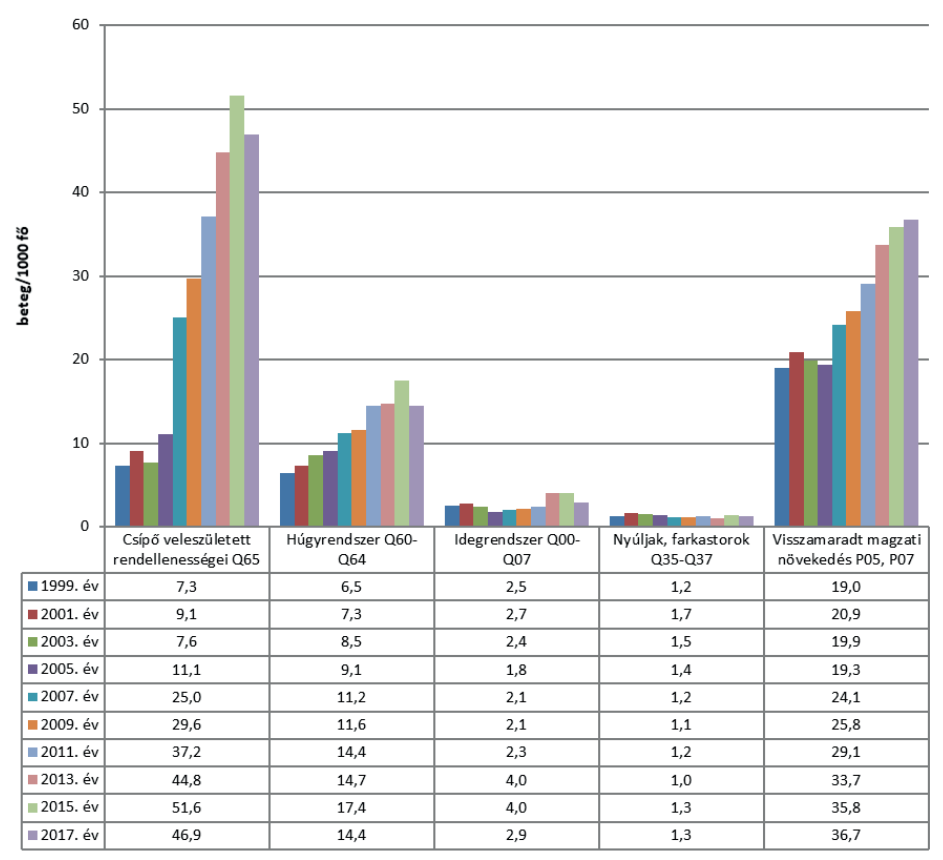

5. ábra: Szülés körüli anomáliák, veleszületett rendellenességek a 0-11 hónapos korcsoportban 1000 före az OSAP 1021 alapján 1999-2017. években Magyarországon 
Az egyes betegségekkel regisztrált betegek abszolút számát, illetve 10000 főre vetített értékét táblázatokban mutatjuk be. A 2. táblázatban a daganatok, magas vérnyomás és egyes vesebetegségekben szenvedők adatai láthatók.

A vérképzőszervi betegségekben szenvedők száma magas volt 1999-ben is, azóta növekedésük töretlen. Összességében 2017-ben a gyermekek 6,2\%-át érintette valamilyen vérképzőszervi betegség. A vashiányos anaemia a teljes gyermekpopulációra vetítve 4,1\% (3. táblázat)

Az endokrin, táplálkozási és anyagcsere betegségek csoportjában a betegek száma háromszorosára nőtt, annak ellenére, hogy egyes betegségek miatti esetek száma a csoporton belül csökkent (4. táblázat). A jódhiányos golyvával kezeltek száma megfeleződött, stagnált a fehérjehiányos alultápláltság. A kalóriatöbblet miatti elhízás az egyedi BNO (E66.0) szerint csökkent.

A cisztás fibrózist - bár genetikai betegség -, tekintettel arra, hogy az anyagcsere folyamatokra van hatása, ebben a csoportban követhetjük nyomon.

Az intestinalis malabsorptio a jelentések alapján megháromszorozódott, mintegy 11000 gyermeket érintett már 2017. évben. E betegségkör felét a coeliakia adja.

A mentális viselkedési zavarokkal kezeltek (F00-F99) nyilvántartott száma is megduplázódott (5. táblázat). E csoporton belül csak a mentális retardációba sorolt esetek száma csökkent, viszont a viselkedési zavarok száma megháromszorozódott.

Az allergiás alapon kialakuló betegségek közül az asztma a gyermekpopuláció mintegy 6,3\%-át érintette 2017-ben (6. táblázat). A jelentések alapján a vizsgált időszak alatt számuk megkétszereződött. Az allergiás bőrbetegségek közül az atópiás dermatitis a 0-18 évesek 5,4\%-ánál ismert a háziorvosi, házi gyermekorvosi nyilvántartásban. A psoriásisok száma - a vizsgált rövidebb időszak alatt is - jelentős növekedést mutat.

A mozgásszervi betegségek közül a hátgerinc deformitások előfordulása kiemelkedő, a 0-18 évesek 3,1\%-át érintik (7. táblázat). Kisebb számú, de számszerüen kétszeresére, arányában háromszorosára nőtt a fiatalkori ízületi gyulladásos megbetegedések száma is.
A háziorvosok, házi gyermekorvosok által jelentett születés körüli eseményeket, veleszületett rendellenességeket a 8. táblázatban foglaltuk össze. A viszszamaradt magzati növekedés, alultápláltság, rövid terhességi időtartammal és alacsony születési súllya összefüggő rendellenességek megháromszorozódtak a vizsgált időszakban. Megduplázódott a keringés rendszer és a húgyrendszer veleszületett rendellenességeinek száma is. A csípő veleszületett deformitásai ugyan összesen 10000 gyermeket érintenek, de a többszörösére emelkedtek. Elsősorban nem egészségügyi, inkább szociális probléma az elhanyagolás, ami a jelentések szerint sokat javult az elmúlt közel 2 évtizedben.

Az érzékszervek közül a szem betegségeiből a vakság esetszáma jelentősen mérséklődött, viszont a szemizmok, a binoculáris szemmozgás, az alkalmazkodás és a fénytörés betegségeinek (H49-H52) esetszáma nőtt (9. táblázat). A hallószerv betegségei is egyre több fiatalt érintenek.

\section{Korcsoportonkénti különbségek}

Az általunk vizsgált legutolsó évre - 2017. - 10000 megfelelő korú (0-11 hó, 1-4 év, 5-14 év, 15-18 év) gyermekre vetítve is vizsgáltuk a megbetegedési arányokat (10. táblázat). (A táblázat 22 betegséget tartalmaz, melyeknek esetszámait a KSH-tól külön korcsoportonként is megkaptuk.) Jellemzően a kor elörehaladtával a betegségek előfordulása növekszik, egy-két kivételtől eltekintve, mint pl. a fehérje- és energiahiányos alultápláltság, elhanyagolás, elhagyás. A növekedés a 0 évestől a 15-18 éves korra meghaladja a 10-szeres mértéket a diabetes mellitus, az asztma, a szemizmok, a binokuláris szemmozgás, az alkalmazkodás és a fénytörés betegségei, a vakság, csökkentlátás, magas vérnyomás, deformáló hátgerinc változások esetén. Többféle típusú veleszületett rendellenesség jelentett esetszáma csökken a nagyobb gyermekeknél (húgyrendszer, csípő veleszületett rendellenessége, ajak- és szájpad hasadék). 
2. táblázat: Rosszindulatú daganatok, hypertensiv betegségek és glomerularis betegségek miatt nyilvántartott betegek száma és 10000 före vetített aránya az OSAP 1021 alapján 0-18 éves korban, 1999-2017. években Magyarországon

\begin{tabular}{|c|c|c|c|c|c|c|c|c|c|c|}
\hline \multirow{2}{*}{ Betegség } & \multicolumn{10}{|c|}{ Idöszak (év) } \\
\hline & 1999. & 2001. & 2003. & 2005. & 2007. & 2009. & 2011. & 2013. & 2015. & 2017. \\
\hline $\begin{array}{l}\text { Rosszindula- } \\
\text { tú daganatok } \\
\text { (COO-C97) }\end{array}$ & 1280 & 1479 & 1509 & 1410 & 1668 & 1756 & 1738 & 1870 & 2186 & 2126 \\
\hline 10000 före & 5,7 & 6,7 & 7,1 & 6,8 & 8,3 & 8,9 & 9,1 & 10 & 12 & 11,7 \\
\hline $\begin{array}{l}\text { Hypertensiv } \\
\text { betegségek } \\
\text { (110-115) }\end{array}$ & 7260 & 7655 & 8814 & 9435 & 10643 & 12202 & 12185 & 11642 & 11767 & 10799 \\
\hline 10000 före & 32,5 & 34,8 & 41,3 & 45,7 & 52,8 & 62 & 64 & 62,5 & 64,6 & 59,6 \\
\hline $\begin{array}{l}\text { Glomerularis } \\
\text { betegségek } \\
\text { (N00-N08), } \\
\text { (N10-N16) }\end{array}$ & 3306 & 3600 & 4254 & 4770 & 6084 & 6246 & 6081 & 6047 & 6258 & 6665 \\
\hline 10000 före & 14,7 & 16,4 & 19,9 & 23,1 & 30,2 & 31,8 & 31,9 & 32,4 & 34,3 & 36,8 \\
\hline
\end{tabular}

3. táblázat: Vér és vérképzőszervi betegségek miatt nyilvántartott betegek száma és 10000 före vetített aránya az OSAP 1021 alapján 0-18 éves korban, 1999-2017. években Magyarországon

\begin{tabular}{|c|c|c|c|c|c|c|c|c|c|c|}
\hline \multirow{2}{*}{ Betegség } & \multicolumn{10}{|c|}{ Időszak (év) } \\
\hline & 1999. & 2001. & 2003. & 2005. & 2007. & 2009. & 2011. & 2013. & 2015. & 2017. \\
\hline $\begin{array}{l}\text { A vér és vér- } \\
\text { képző szervek } \\
\text { betegségei } \\
\text { és az immun- } \\
\text { rendszert } \\
\text { érintő bizonyos } \\
\text { rendellenessé- } \\
\text { gek (D50-D89) }\end{array}$ & 60451 & 66586 & 66998 & 66574 & 77466 & 85335 & 92700 & 101832 & 111344 & 112333 \\
\hline 10000 före & 268,3 & 302,8 & 314,1 & 322,3 & 384,2 & 433,9 & 486,9 & 546,4 & 610 & 619,9 \\
\hline $\begin{array}{l}\text { Vashiányos } \\
\text { anaemia (D50) }\end{array}$ & 52333 & 57236 & 56414 & 54873 & 59245 & 60657 & 64951 & 71573 & 75946 & 74392 \\
\hline 10000 före & 232,3 & 206,3 & 264,4 & 265,7 & 293,9 & 308,4 & 341,2 & 384 & 416,1 & 410,6 \\
\hline $\begin{array}{l}\text { Véralvadási de- } \\
\text { fektusok (D65. } \\
\text { D69) }\end{array}$ & 1313 & 1573 & 1774 & 2132 & 3071 & 2602 & 2747 & 2945 & 3453 & 3983 \\
\hline 10000 före & 5,8 & 7,2 & 8,3 & 10,3 & 15,2 & 13,2 & 14,4 & 15,8 & 18,9 & 22 \\
\hline
\end{tabular}


4. táblázat: Endokrin és anyagcsere betegségben szenvedők száma és 10000 före vetített aránya az OSAP 1021 alapján 0-18 éves korban, 1999-2017. években Magyarországon

\begin{tabular}{|c|c|c|c|c|c|c|c|c|c|c|}
\hline \multirow{2}{*}{ Betegség } & \multicolumn{10}{|c|}{ Időszak (év) } \\
\hline & 1999. & 2001. & 2003. & 2005. & 2007. & 2009. & 2011. & 2013. & 2015. & 2017. \\
\hline $\begin{array}{l}\text { Endokrin, táplál- } \\
\text { kozási és anyag- } \\
\text { csere betegségek } \\
\text { (EOO-E9O) }\end{array}$ & 47234 & 53902 & 62180 & 69751 & 82811 & 88131 & 92023 & 108566 & $1 E+05$ & 146638 \\
\hline 10000 före & 209,6 & 245,1 & 291,5 & 337,7 & 410,7 & 448,1 & 483,4 & 582,5 & 719,9 & 809,3 \\
\hline $\begin{array}{l}\text { Jódhiányhoz társuló } \\
\text { diffúz (endémiás) } \\
\text { golyva (EO1.O) }\end{array}$ & 1434 & 1308 & 1353 & 1344 & 1015 & 1025 & 897 & 896 & 946 & 747 \\
\hline 10000 före & 6,4 & 5,9 & 6,3 & 6,5 & 5 & 5,2 & 4,7 & 4,8 & 5,2 & 4,1 \\
\hline $\begin{array}{l}\text { Diabetes mellitus } \\
\text { (E10-E14) }\end{array}$ & 2398 & 2555 & 2657 & 2828 & 3334 & 3985 & 4331 & 4368 & 4632 & 4954 \\
\hline 10000 före & 10,6 & 11,6 & 12,5 & 13,7 & 16,5 & 20,3 & 22,8 & 23,4 & 25,4 & 27,3 \\
\hline $\begin{array}{l}\text { Fehérje- és energia- } \\
\text { hiányos alultápláltság } \\
\text { (E43-E44) }\end{array}$ & 2802 & 2704 & 2516 & 2237 & 2273 & 2492 & 2377 & 2826 & 2825 & 2698 \\
\hline 10000 före & 12,4 & 12,3 & 11,8 & 10,8 & 11,3 & 12,7 & 12,5 & 15,2 & 15,5 & 14,9 \\
\hline Rachitis, aktív (E55.0) & 952 & 551 & 566 & 425 & 1988 & & & & & \\
\hline 10000 före & 4,2 & 2,5 & 2,7 & 2,1 & 9,9 & & & & & \\
\hline Fibrosis cystica (E84) & 464 & 546 & 713 & 912 & 648 & 755 & 723 & 640 & 760 & 740 \\
\hline 10000 före & 2,1 & 2,5 & 3,3 & 4,4 & 3,2 & 3,8 & 3,8 & 3,4 & 4,2 & 4,1 \\
\hline $\begin{array}{l}\text { Kalóriatöbblet miatti } \\
\text { elhízás (E66.0) }\end{array}$ & 31495 & 35928 & 42028 & 47334 & 50094 & 43767 & 41355 & 36143 & 35592 & 30238 \\
\hline 10000 före & 139,8 & 163,4 & 197 & 229,2 & 248,5 & 222,5 & 217,2 & 193,9 & 195 & 166,9 \\
\hline $\begin{array}{l}\text { Gyomor-, nyombél-, } \\
\text { gastrojejunális fekély } \\
\text { (K25-K28) }\end{array}$ & 902 & 1041 & 1059 & 1257 & 1412 & 1434 & 1309 & 1749 & 1549 & 952 \\
\hline 10000 före & 4 & 4,7 & 5 & 6,1 & 7 & 7,3 & 6,9 & 9,4 & 8,5 & 5,3 \\
\hline $\begin{array}{l}\text { Intestinalis malabsor- } \\
\text { ptio (K90) }\end{array}$ & 3987 & 4557 & 4803 & 5430 & 7776 & 7963 & 8444 & 9303 & 10840 & 11152 \\
\hline 10000 före & 17,7 & 20,7 & 22,5 & 26,3 & 38,6 & 40,5 & 44,4 & 49,9 & 59,4 & 61,5 \\
\hline Coeliakia (K90.0) & 1116 & 1361 & 1690 & 2418 & 2984 & 3669 & 4319 & 4667 & 5500 & 5821 \\
\hline 10000 före & 5 & 6,2 & 7,9 & 11,7 & 14,8 & 18,7 & 22,7 & 25 & 30,1 & 32,1 \\
\hline
\end{tabular}


5. táblázat: Mentális- és viselkedészavarok, idegrendszeri betegek száma és 10000 före vetített aránya az OSAP 1021 alapján 0-18 éves korban, 1999-2017. években Magyarországon

\begin{tabular}{|c|c|c|c|c|c|c|c|c|c|c|}
\hline \multirow{2}{*}{ Betegség } & \multicolumn{10}{|c|}{ Időszak (év) } \\
\hline & 1999. & 2001. & 2003. & 2005. & 2007. & 2009. & 2011. & 2013. & 2015. & 2017. \\
\hline $\begin{array}{l}\text { Mentális- és vi- } \\
\text { selkedészavarok } \\
\text { (FO0-F99) }\end{array}$ & 31005 & 33244 & 34645 & 35692 & 39976 & 43294 & 46542 & 50347 & 58922 & 65670 \\
\hline 10000 före & 137,6 & 151,2 & 162,4 & 172,8 & 198,3 & 220,1 & 244,5 & 270,1 & 322,8 & 362,4 \\
\hline $\begin{array}{l}\text { Pszichoaktív szer } \\
\text { használata által } \\
\text { okozott mentális } \\
\text { és viselkedés zava- } \\
\text { rok (F10-F19) }\end{array}$ & 368 & 463 & 461 & 629 & 416 & 656 & 1043 & 671 & 1002 & 1023 \\
\hline 10000 före & 1,6 & 2,1 & 2,2 & 3 & 2,1 & 3,3 & 5,5 & 3,6 & 5,5 & 5,6 \\
\hline $\begin{array}{l}\text { Szomatoform } \\
\text { rendellenességek } \\
\text { (F45) }\end{array}$ & 1776 & 1708 & 1738 & 1685 & 1678 & 1705 & 1718 & 1732 & 1865 & 1973 \\
\hline 10000 före & 7,9 & 7,8 & 8,1 & 8,2 & 8,3 & 8,7 & 9 & 9,3 & 10,2 & 10,9 \\
\hline $\begin{array}{l}\text { Mentális retardatio } \\
\text { (F70-F79) }\end{array}$ & 13114 & 13336 & 13087 & 11987 & 12334 & 11594 & 11226 & 10736 & 11439 & 11404 \\
\hline 10000 före & 58,2 & 60,6 & 61,3 & 58 & 61,2 & 58,9 & 59 & 57,6 & 62,7 & 62,9 \\
\hline $\begin{array}{l}\text { A psychés fejlődés } \\
\text { rendellenességei, } \\
\text { hyperkineticus, } \\
\text { magatartási és } \\
\text { emocio }\end{array}$ & 9109 & 10649 & 11241 & 12096 & 15794 & 15703 & 18474 & 21251 & 26483 & 31643 \\
\hline 10000 före & 40,4 & 48,4 & 52,7 & 58,2 & 78,3 & 79,8 & 97 & 114 & 145,1 & 174,6 \\
\hline Epilepsia (G40) & 8842 & 9239 & 9418 & 9605 & 11401 & 12054 & 11709 & 11690 & 12318 & 12398 \\
\hline 10000 före & 39,2 & 42 & 44,1 & 46,5 & 56,5 & 61,3 & 61,5 & 62,7 & 67,5 & 68,4 \\
\hline $\begin{array}{l}\text { Csecsemőkori agyi } \\
\text { bénulás (G80) }\end{array}$ & 1551 & 1780 & 1601 & 1889 & 2076 & 2140 & 2134 & 2238 & 2845 & 2718 \\
\hline 10000 före & 6,9 & 8,1 & 7,5 & 9,1 & 10,3 & 10,9 & 11,2 & 12 & 15,6 & 15 \\
\hline
\end{tabular}


6. táblázat: Egyes allergia alapú betegséggel kezeltek száma és 10000 före vetített aránya az OSAP 1021 alapján 0-18 éves korban, 1999-2017. években Magyarországon

\begin{tabular}{|c|c|c|c|c|c|c|c|c|c|c|}
\hline \multirow{2}{*}{ Betegség } & \multicolumn{10}{|c|}{ Idöszak (év) } \\
\hline & 1999. & 2001. & 2003. & 2005. & 2007. & 2009. & 2011. & 2013. & 2015. & 2017. \\
\hline Asztma (J45) & 41783 & 47859 & 51857 & 58908 & 79776 & 92993 & 103644 & 107060 & 113863 & 114673 \\
\hline 10000 före & 185,4 & 217,7 & 243,1 & 285,2 & 395,7 & 472,8 & 544,4 & 574,2 & 623,8 & 632,9 \\
\hline $\begin{array}{l}\text { Atopiás derma- } \\
\text { titis (L20) }\end{array}$ & 28482 & 33902 & 37250 & 44419 & 73125 & 75937 & 82401 & 85034 & 91379 & 97474 \\
\hline 10000 före & 126,4 & 154,2 & 174,6 & 215,1 & 362,7 & 386,1 & 432,8 & 456,2 & 500,6 & 537,9 \\
\hline Psoriasis (L40) & n.a. & n.a. & n.a. & n.a. & n.a. & 1326 & 1834 & 1784 & 1924 & 2153 \\
\hline 10000 före & & & & & & 6,7 & 9,6 & 9,6 & 10,5 & 11,9 \\
\hline
\end{tabular}

7. táblázat: Egyes mozgásszervi betegségben szenvedők száma és 10000 före vetített aránya az OSAP 1021 alapján 0-18 éves korban, 1999-2017. években Magyarországon

\begin{tabular}{|c|c|c|c|c|c|c|c|c|c|c|}
\hline \multirow{2}{*}{ Betegség } & \multicolumn{10}{|c|}{ Idöszak (év) } \\
\hline & 1999. & 2001. & 2003. & 2005. & 2007. & 2009. & 2011. & 2013. & 2015. & 2017. \\
\hline $\begin{array}{l}\text { Fiatalkori ízü- } \\
\text { leti gyulladás } \\
\text { (M08) }\end{array}$ & 1318 & 1411 & 1645 & 1810 & 2168 & 1860 & 1862 & 2122 & 2733 & 2839 \\
\hline 10000 före & 5,8 & 6,4 & 7,7 & 8,8 & 10,8 & 9,5 & 9,8 & 11,4 & 15 & 15,7 \\
\hline $\begin{array}{l}\text { Deformáló } \\
\text { hátgerinc-el- } \\
\text { változások } \\
\text { (M40-M43) }\end{array}$ & 34977 & 41125 & 44900 & 47424 & 52232 & 48049 & 50525 & 54499 & 57883 & 56955 \\
\hline 10000 före & 155,2 & 187 & 210,5 & 229,6 & 259,1 & 244,3 & 265,4 & 292,4 & 317,1 & 314,3 \\
\hline $\begin{array}{l}\text { A csípő és me- } \\
\text { dence juvenilis } \\
\text { osteochondro- } \\
\text { sisa (M91) }\end{array}$ & 690 & 794 & 1106 & 1011 & 1257 & 1133 & 1210 & 1157 & 1344 & 978 \\
\hline 10000 före & 3,1 & 3,6 & 5,2 & 4,9 & 6,2 & 5,8 & 6,4 & 6,2 & 7,4 & 5,4 \\
\hline
\end{tabular}


8. táblázat: Születéskörüli események és veleszületett rendellenességek száma és 10000 före vetített aránya az OSAP 1021 alapján 0-18 éves korban, 1999-2017. években Magyarországon

\begin{tabular}{|c|c|c|c|c|c|c|c|c|c|c|}
\hline \multirow{2}{*}{ Betegség } & \multicolumn{10}{|c|}{ Idöszak (év) } \\
\hline & 1999. & 2001. & 2003. & 2005. & 2007. & 2009. & 2011. & 2013. & 2015. & 2017. \\
\hline $\begin{array}{l}\text { Visszamaradt } \\
\text { magzati nö- } \\
\text { vekedés és } \\
\text { alultápláltság, } \\
\text { a rövid terhes- } \\
\text { ségi időtartam- } \\
\text { mal és alacsony } \\
\text { születési súllyal } \\
\text { kapcsolatos } \\
\text { m.n.o. rendelle- } \\
\text { nességek (P05, } \\
\text { P07) }\end{array}$ & 5232 & 5011 & 5131 & 5343 & 6643 & 8283 & 8909 & 10717 & 12898 & 15518 \\
\hline 10000 före & 23,2 & 22,8 & 24,1 & 25,9 & 32,9 & 42,1 & 46,8 & 57,5 & 70,7 & 85,6 \\
\hline $\begin{array}{l}\text { Az idegrendszer } \\
\text { veleszületett } \\
\text { rendellenességei } \\
\text { (Q0O-Q07) }\end{array}$ & 3453 & 3455 & 3296 & 3009 & 2600 & 2586 & 2345 & 2586 & 3042 & 3006 \\
\hline 10000 före & 15,3 & 15,7 & 15,1 & 14,6 & 12,9 & 13,1 & 12,3 & 13,9 & 16,7 & 16,6 \\
\hline $\begin{array}{l}\text { A keringési } \\
\text { rendszer vele- } \\
\text { született ren- } \\
\text { dellenességei } \\
\text { (Q2O-Q28) }\end{array}$ & 9332 & 9688 & 10966 & 11788 & 13865 & 15617 & 16382 & 17975 & 19842 & 21454 \\
\hline 10000 före & 41,4 & 44,1 & 51,4 & 57,1 & 68,8 & 79,4 & 86,1 & 96,4 & 108,7 & 118,4 \\
\hline $\begin{array}{l}\text { Ajak- és szájpad- } \\
\text { hasadék (nyúla- } \\
\text { jak és farkasto- } \\
\text { rok) (Q35-Q37) }\end{array}$ & 1959 & 1916 & 1793 & 1739 & 1677 & 1656 & 1706 & 1676 & 1748 & 1840 \\
\hline 10000 före & 8,7 & 8,7 & 8,4 & 8,4 & 8,3 & 8,4 & 9 & 9 & 9,6 & 10,2 \\
\hline $\begin{array}{l}\text { A húgyrend- } \\
\text { szer veleszü- } \\
\text { letett rendel- } \\
\text { lenességei } \\
\text { (Q60-Q64) }\end{array}$ & 5232 & 5711 & 6289 & 6876 & 8026 & 9479 & 10088 & 11052 & 12275 & 12717 \\
\hline 10000 före & 23,2 & 26 & 29,5 & 33,3 & 39,8 & 48,2 & 53 & 59,3 & 67,3 & 70,2 \\
\hline $\begin{array}{l}\text { A csípő vele- } \\
\text { született defor- } \\
\text { mitásai (Q65) }\end{array}$ & 1916 & 2184 & 2144 & 2583 & 5132 & 6075 & 6564 & 7945 & 9738 & 10306 \\
\hline 10000 före & 8,5 & 9,9 & 10,1 & 12,5 & 25,5 & 30,9 & 34,5 & 42,6 & 53,4 & 56,9 \\
\hline $\begin{array}{l}\text { Elhanyagolás } \\
\text { vagy elhagyás } \\
\text { (YO6) }\end{array}$ & 6514 & 6174 & 5461 & 4391 & 3045 & 2948 & 2117 & 1679 & 1535 & 1127 \\
\hline 10000 före & 28,9 & 28,1 & 25,6 & 21,3 & 15,1 & 15 & 11,1 & 9 & 8,4 & 6,2 \\
\hline
\end{tabular}


9. táblázat: A látó- és hallószerv egyes betegségeinek száma és 10000 före vetített aránya az OSAP 1021 alapján 0-18 éves korban, 1999-2017. években Magyarországon

\begin{tabular}{|c|c|c|c|c|c|c|c|c|c|c|}
\hline \multirow{2}{*}{ Betegség } & \multicolumn{10}{|c|}{ Idöszak (év) } \\
\hline & 1999. & 2001. & 2003. & 2005. & 2007. & 2009. & 2011. & 2013. & 2015. & 2017. \\
\hline $\begin{array}{l}\text { A szemizmok, a bino- } \\
\text { culáris szemmozgás, } \\
\text { az alkalmazkodás és a } \\
\text { fénytörés betegségei } \\
\text { (H49-H52) }\end{array}$ & 47968 & 51883 & 54016 & 54772 & 55327 & 52907 & 52234 & 52538 & 55784 & 58707 \\
\hline 10000 före & 212,9 & 236 & 253,2 & 265,2 & 274,4 & 269 & 274,4 & 281,9 & 305,6 & 324 \\
\hline $\begin{array}{l}\text { Vakság és csökkentlá- } \\
\text { tás (H54) }\end{array}$ & 6728 & 5549 & 5705 & 4406 & 4092 & 3756 & 2923 & 2729 & 3184 & 2351 \\
\hline 10000 före & 29,9 & 25,2 & 26,7 & 21,3 & 20,3 & 19,1 & 15,4 & 14,6 & 17,4 & 13 \\
\hline $\begin{array}{l}\text { Vezetéses típusú, ide- } \\
\text { gi eredetú és egyéb } \\
\text { hallásvesztés (H90, } \\
\text { H91) }\end{array}$ & 4153 & 4295 & 4210 & 4305 & 5145 & 5040 & 5328 & 5687 & 6287 & 6531 \\
\hline 10000 före & 18,4 & 19,5 & 19,7 & 20,8 & 25,5 & 25,6 & 28 & 30,5 & 34,4 & 36 \\
\hline
\end{tabular}

10. táblázat Egyes kórképek miatti regisztrált esetek aránya korcsoportonként 10000 megfelelő korú gyermekre

\begin{tabular}{|c|c|c|c|c|}
\hline Betegség & 0-11 hó & 1-4 év & 5-14 év & 15-18 év \\
\hline Rosszindulatú daganatok & 2,4 & 6,9 & 12,2 & 17,5 \\
\hline $\begin{array}{l}\text { A vér és a vérképző szervek és az immunrendszert érintő bizo- } \\
\text { nyos rendellenességek) }\end{array}$ & 440,8 & 647,7 & 572,0 & 755,5 \\
\hline Ebből: vashiányos anémia & 297,7 & 417,8 & 376,9 & 514,4 \\
\hline Diabetes mellitus & 1,1 & 7,5 & 27,1 & 53,3 \\
\hline Fehérje- és energiahiányos alultápláltság & 19,1 & 23,1 & 12,1 & 13,0 \\
\hline Kalóriatöbblet miatti elhízás & 29,7 & 67,8 & 160,8 & 309,8 \\
\hline Epilepszia & 11,3 & 38,1 & 75,9 & 92,8 \\
\hline $\begin{array}{l}\text { A szemizmok, a binokuláris szemmozgás, az alkalmazkodás és } \\
\text { a fénytörés betegségei }\end{array}$ & 20,2 & 131,8 & 354,9 & 505,3 \\
\hline Vakság és csökkentlátás & 0,9 & 5,5 & 13,3 & 22,3 \\
\hline Vezetéses típusú, idegi eredetű és egyéb hallásvesztés & 11,7 & 25,2 & 42,0 & 37,7 \\
\hline Magasvérnyomás-betegségek & 1,8 & 6,4 & 34,6 & 185,7 \\
\hline Asztma & 53,8 & 460,0 & 739,5 & 676,7 \\
\hline Atopiás dermatitis & 813,2 & 834,1 & 484,7 & 320,7 \\
\hline
\end{tabular}




\begin{tabular}{|c|c|c|c|c|}
\hline Deformáló hátgerinc-elváltozások & 21,8 & 27,3 & 310,9 & 667,7 \\
\hline $\begin{array}{l}\text { Glomeruláris betegségek, renális tubulointerstitialis betegsé- } \\
\text { gek }\end{array}$ & 25,3 & 38,7 & 36,5 & 38,4 \\
\hline $\begin{array}{l}\text { Visszamaradt magzati növekedéssel kapcsolatos rendellenes- } \\
\text { ségek }\end{array}$ & 368,5 & 169,5 & 53,1 & 17,3 \\
\hline Az idegrendszer veleszületett rendellenességei & 29,2 & 18,9 & 14,9 & 15,4 \\
\hline A keringési rendszer veleszületett rendellenességei & 160,2 & 151,7 & 115,5 & 83,9 \\
\hline Ajak- és szájpadhasadék & 12,6 & 11,0 & 10,4 & 8,1 \\
\hline A húgyrendszer veleszületett rendellenességei & 144,8 & 92,5 & 65,7 & 41,9 \\
\hline A csípő veleszületett deformitásai & 471,4 & 100,0 & 18,5 & 10,0 \\
\hline Elhanyagolás vagy elhagyás & 13,0 & 8,1 & 5,0 & 5,8 \\
\hline
\end{tabular}

\section{Nemenként különbségek}

A nemek közötti különbséget 2017-re vonatkozóan vizsgáltuk. Összességében a különbség nem jelentős, ha az abszolút számokat nézzük: a 39 betegség/betegségcsoportban fiúk esetén 336 645, lányoknál 317663 eset került jelentésre. Fiúk aránya a lányokhoz képest 106\%. Egyes betegségek azonban fiúknál lényegesen magasabb arányban fordultak elő, mint a lányoknál. Ilyenek: a mentális viselkedési zavarok (173\%), mentális retardáció (185\%), psychés fejlődési rendellenesség (239\%). Szervi betegségek közül a magas vérnyomás (183\%), asztma (156\%), csípő és medence (165\%), ajakés szájpadhasadék (152\%), húgyrendszer veleszületett betegségeinek esetszáma volt magasabb (158\%).

\section{Megbeszélés}

Az OSAP 1021-es háziorvosi, házi gyermekorvosi statisztikai jelentések 39 betegség prevalenciájáról adnak képet. A hosszú éveken keresztül végzett adatszolgáltatás sok információt nyújt, és lehetőséget teremt arra, hogy megvizsgáljuk, hogyan változott 19 év alatt a gyermekek egészségi állapota.

Látható, hogy megduplázódott a háziorvosok által kezelt krónikus betegek száma, ez jelentős terhet ró az alapellátásra is. (Értelemszerüen csak azokat a betegségeket vesszük figyelembe, amelyek a jelentésben szerepelnek - ezen kívül számos krónikus betegség lehetne még a listán.)

Fentiek figyelembevételével adjuk közre az elemzésből leszürt következtetéseinket.
A monitorozott betegségek 1/4-ében csökkentek az esetszámok. Pozitív változás, ami feltehetően a szociális helyzet javulásának tudható be, hogy 2017-ben az elhanyagolás a kiindulási évben jelzetthez képest 17\%-ra csökkent. A vakság és gyengénlátás előfordulása 34\%-ra esett vissza. Ennek oka lehet a javuló koraszülött ellátás.

Abban, hogy a jódhiányhoz társuló diffúz golyva esetek száma a felére csökkent, a diagnosztika pontosabbá válásán kivül a jódozott só elterjedése is szerepet játszhat. A közétkeztetésben a 37/2014. (IV.30.) EMMI rendelet kötelezi a cégeket a jódozott só használatára. Bár feltehető, hogy a diagnózis módszerében is bekövetkezett a kedvező eredményt adó változtatás.

Az OSAP jelentések alapján csökkent a kalóriatöbblet miatti elhízás. Ez az eredmény nincs összhangban más adatokkal'. A COSI 2016 (Gyermek Tápláltsági Állapot Vizsgálata, angolul, Childhood Obesity Surveillance Initiative), szerint 2010. óta az adatok stabilitást mutatnak, mely szerint a túlsúlyosok és az elhízottak aránya is 10-10\% körül van Magyarországon. Esetünkben 3\%-nyi a kalóriabevitel miatti túlsúlyosak aránya. Valószínúsíthetö, hogy az elhízottak egy része az endokrin és táplálkozási anyagcsere betegségek BNO alatt (EOO-E9O k.m.n) szerepel, ezek száma ugyanis mással nem magyarázható módon jelentősen megugrott. Az elhízás több betegség szempontjából is nagyon fontos kockázati tényező, ezért a továbbiakban érdemes lenne ennek jelentését egyértelmúen meghatározni, és egyetlen BNO alá besorolni.

A cukorbetegség előfordulása, mely az anyagcserebetegségeken belül külön is jelentésre kerül, kétszeres növekedést mutat. A jelentésben nem válik el az I-es és II. típusú diabetes. Ezen célszerú lenne változtatni. 
Az emésztörendszer betegségei között 5-szörös emelkedésével figyelmet érdemel a coeliakia. Ennek részben oka lehet a javuló diagnosztika, de a táplálék összetétele, és a felszívódást megváltoztató környezeti tényezők (pl. a tenzidek) is? . Közel háromszorosára nőtt az intestinalis malabszorptio prevalenciája is. Lényegében változatlan maradt a gyomor és nyombélfekély előfordulása a gyermekek körében.

A szív-és érrendszeri betegségek közül hosszú éveken át nőtt a magas vérnyomás betegség száma, jellemzően a fiúk körében. Az utóbbi években látható csökkenés részben abból adódik, hogy a 15-18 éves korcsoport, ahol magasabb a hypertóniások száma, kisebb létszámú lett. (1999-ben még 522.224 fő, 2017ben 389.610 fö volt ebben a korcsoportban.) Meg kell jegyezni, hogy a keringés veleszületett rendellenességei BNO alatt szereplő bejelentett esetek száma is két és félszeresére nőtt a vizsgált időszakban.

A biológiai és vegyi, környezeti expozíció és az immunrendszer kóros múködése következtében az asztma 2,74-, a psoriasis 1,62-, az atópiás dermatitis prevalenciája 3,42-szeres növekedést mutat.

Átlagot meghaladóan nőtt a mentális viselkedési zavarok, a pszichés fejlődési rendellenességek és a pszichoaktív szerek fogyasztásából eredő mentális problémák száma is. 2017-ben ezek a betegségek miatt több mint 65.000 esetet regisztráltak. Bár a szám magasnak tûnik, de egyes pszichiáterek becslése szerint a kórkép csoport a gyermekpopuláció 25\%-ában fordul elő ${ }^{8}$. Az eltérés (cc. 20\%) nagyon jelentős. Valószínü, hogy az elmúlt években sokkal érzékenyebbé váltak a vizsgálatok, több kórkép pontosabban meghatározható, tehát érdemes lenne a háziorvosi jelentésben szereplő BNOkat is felülvizsgálni, bővíteni.

Az idegrendszeri betegségek közül figyelmet érdemel az epilepszia, melynek regisztrált esetszáma 8.842ről 12.398-ra nőtt 19 év alatt a gyermekek körében.

Nagyszámú, és növekedést mutat a mozgásszervi betegségekkel küzdő gyermekek és ifjak száma is, kiemelten a deformáló hátgerincváltozások. Ezek nagy része a gyenge hátizmok, tartási rendellenességek következménye.

Jellemző, hogy a nem veleszületett betegségek a kor elörehaladtával fokozatosan gyakoribbá válnak, vagy kumulálódnak, ahogy a 3. táblázatban is látható. Ebben a táplálkozásnak, egyéb környezeti tényezőknek feltehetően jelentős szerep van.

A veleszületett rendellenességek aránya korcsoportonként csökken. Ennek oka lehet a gyermek halála, illetve az esetek többségében a betegség mütéti kor- rekciója. A háziorvosi jelentések adatai nagyban egyeznek a VRONY adataival - azokat a veleszületett rendellenességeket illetően, melyek mindkét rendszerben megjelennek ${ }^{9}$.

Az OSAP 1021 adatai alapján a csípő veleszületett rendellenességeinek esetszámai nőttek meg legjobban, 5-szörös mértékben, aminek okát érdemes lenne külön vizsgálni. Feltehetően változás történt a diagnózis terén. Több, mint 2-szeresre emelkedett a vizsgált években a húgyúti és keringési rendszer veleszületett rendellenességeinek száma is.

A terhességgel, illetve születés körüli eseményekkel hozható összefüggésbe a visszamaradt magzati növekedés és alultápláltság, a rövid terhességi időtartammal és alacsony születési súllyal kapcsolatos rendellenességek, melyek közel 3-szor gyakoribbá váltak. Ez abból adódhat, hogy a koraszülöttek aránya gyakorlatilag nem változott, a csecsemőhalálozás viszont csökkent ${ }^{10}$, így egyre több (nagyon) kis súlyú és/ vagy korán született csecsemő maradt életben.

A csecsemőkori agyi bénulás 1,75-szörösére nőtt a 0-18 éves korcsoportban. Az arány elgondolkodtató annak tükrében, hogy a születés körüli agyi oxigénhiányt a császármetszések - melyeket hazánkban átlagosan közel 40\%-os arányban végeznek -, kiküszöbölik"1.

Egy 2015-ben végzett kutatás, mely az 1980-1996. közötti veleszületett rendellenességeket dolgozta fel az anya kora alapján, nem mutatta ki, hogy az idősebb kor nagyobb kockázatot jelentene bizonyos veleszületett rendellenességek tekintetében ${ }^{12}$. A dohányzás és a veleszületett rendellenességek, illetve koraszülés közötti kapcsolatot viszont több közlemény is megerősítette ${ }^{13}$. Jelentős eltérés van a dohányzó terhes nők gyakoriságát illetően: Valencia tartományban 18,3\%, míg Norvégiában 3,6\%-a dohányzott a nőknek a terhesség 2. felében. Hazánkban a 2014. évi várandós gondozási lap alapján a védőnők által bevitt adatok szerint az első adatfelvételkor Magyarországon átlagosan a terhes nők 21,6\%-a dohányzott - Nyugat-Dunántúlon: 10,1\%, Észak-Magyarország: 42,3\%14. A magzati kort veszélyeztető tényező az anya elhízása is, mely egyre nagyobb arányban fordul elő már a teherbeeséskor ${ }^{15}$.

Jelen közlemény csak az országos adatokat, trendet mutatja be, de a KSH honapján az adatok megyei szinten is szabadon lekérdezhetők, tovább vizsgálhatók.

Összességében az OSAP 1021 adatszolgáltatást hasznos alapnak tartjuk a morbiditási adatok nyomon követésében. Az országos adatsorok felhívják a figyelmet arra, hogy a fiatal generáció egészségi állapota sokat romlott az elmúlt évtizedekben. A betegségek mö- 
gött nagyon sok esetben a születés körüli események állnak, tehát már csecsemőként hátránnyal indul sok kisgyermek, a későbbiekben környezeti, életmódbeli tényezők rontják az egészségi állapotukat.

Az eredmények alapján a következő felnőtt nemzedék egészségi kilátásai feltehetően nem lesznek jobbak a jelenleginél, az egészségügyre háruló költségek pedig növekedni fognak.

Javulás, a betegségterhek csökkenése, a primer prevenciótól várható elsősorban, és csak másodsorban a gyógyító munka hatékonyságától.

Az elektronikus egészségügyi adatszolgáltatás új fejezetet nyit az egészségügyi adatok kezelésében. $A z$ adatok ismeretében néhány elemet érdemes felülvizsgálni, pontosítani, és az utóbbi években elterjedt betegségekkel, illetve életmódi adatokkal (például dohányzás) bővíteni az adatsort. Megfontolandó, hogy az egymással összefüggő adatok (pl. elhízás - diabetes) összekapcsolása megtörténjen. Az adatszolgáltatás korszerüsítésével egy olyan adatbázist lehetne létrehozni, mellyel több, időszakos, reprezentatív mintán történő felmérés is kiváltható lenne.

\section{Anyagi támogatás}

A kutatómunka az EFOP-1.9.6-16 Elektronikus egészségügyi ágazati fejlesztések 2014-2020. C komponens keretében valósult meg.

\section{Szerzök hozzájárulása}

B.M.: adatelemzés, kézirat megszövegezése; K.Zs.: statisztikai tanácsadó; M.B.: projektvezető

\section{Érdekeltségek}

A szerzőknek nincsenek anyagi érdekeltségeik.

\section{Nyilatkozatok}

A cikk végleges változatát valamennyi szerző elolvasta és jóváhagyta.

\section{Irodalomjegyzék}

1. 76/2004. (VIII.19.) ESZCSM rendelet az egyes személyazonosításra alkalmatlan ágazati (egészségügyi, szakmai) adatok körének meghatározására, gyűjtésére, feldolgozására vonatkozó részletes szabályokról
2. 21/2014. (III. 20.) EMMI rendelet a veleszületett rendellenességek bejelentéséről és nyilvántartásuk rendjéről

3. Németh, Á., Költő, A.: Egészség és egészségmagatartás iskoláskorban 2014. Nemzeti Egészségfejlesztési Intézet, 2016.

4. https://mek.oszk.hu/16100/16119/16119.pdf

5. 2016. évi CLV. törvény A hivatalos statisztikáról

6. https://www.ksh.hu/egeszsegugy-baleset

7. Kovács V., Erdei G.: Gyermekkori elhízás előfordulása Magyarországon (COSI) Magyar tudomány 180 (2019) 5, pp. 739-748 https://doi. org/10.1556/2065.180.2019.5.12

8. Fercsákné Csáki, K:: Az emulgeálószerek, avagy hatékony felszívódás fokozó ágensek az élelmiszereinkben. Élelmiszer Tudomány Technológia. LXX. évf., 4. szám, pp.: 2-7

9. https://novekedes.hu/interju/pszichiater-a-gyerekek-negyedenek-mentalis-problemai-vannak-vegyuk-eszre-ezeket

10. A Veleszületett Rendellenességek Országos Nyilvántartás (VRONY) éves jelentése http://www.gyermekalapellatas.hu/vrony/adatok_es_jelentesek

11. http://www.ksh.hu/docs/hun/xftp/stattukor/csecsemohalalozas.pdf

12. http://www.neak.gov.hu//data/cms1025544/Szules_ csaszarmetsz_2015_2019_(2).pdf

13. Csermely, Gy. I.: Az anyai életkor és szülési sorrend hatása a fejlődési rendellenességek kialakulásának kockázatára. Doktori PTE, Doktori Iskola, Pécs, 2015. http://doktoriiskola.etk.pte.hu/public/upload/ files/Doktoriiskola/Tezisfuzetek/CsermelyGy_ert. pdf

14. Pregnancy and Smoking in the EU. European Institue of Woman's Health Policy Brief, 2017.

15. https://eurohealth.ie/wp-content/uploads/2018/05/ Pregnancy-and-Smoking-.pdf

16. Fogarasi-Grenczer, A.: Várandósság alatti dohányzás okai és perinatális kimeneteli eredményei. Semmelweis Egyetem Doktori Iskola Budapest, 2015.

17. https://repo.lib.semmelweis.hu/bitstream/handle/123456789/3999/fogarasigrenczerandrea.d_ DOls.pdf?sequence=1

18. S. Cnattingius, E. Villamor, S. Johansson et al.: Maternal obesity and risk of preterm delivery JAMA2013 Jun 12;309(22):2362-70 https://doi. org/10.1001/jama.2013.6295 